Katarzyna Szorc Uniwersytet w Biatymstoku

\title{
The Emotional Intelligence of Teacher Candidates
}

The human ability to "cope in life" is not, as Daniel Goleman asserted at the end of the 20th century, based only on an individual's cognitive skills. Goleman's assertion decisively changed the way that individuals think about man's "emotional talents," but the reality is that emotional skills are largely congenital, even though current research demonstrates that they can be developed. Indeed, research in the social sciences has been focusing on emotional intelligence, which may be an important determinant of education quality.

This article presents the results of research on the state of the emotional intelligence of students who are preparing to become teachers. This research is part of a broader project that seeks to determine the emotional factors that aid the education process.

Key words: emotional intelligence, teaching candidates.

\section{Introduction}

In recent years, more and more research has concentrated on emotional intelligence (EI), which may be an important determinant in education quality. Researchers have systematically identified the factors that support students' education and the relationships that are important for the learning process. In addition, they have analyzed interventions designed and conducted to improve the quality of the education process ${ }^{1}$ since, needless to say, the quality of education depends largely on teachers.

D. Schunk, Commentary on Self-Regulation in School Contexts, "Learning and Instruction" 2005, 15, pgs. 173-177. 
This study is based on a comprehensive literature review and aims primarily to identify the EI of students from different fields of study who want (or plan) to become teachers.

\section{The Meaning of Emotions and Emotional Intelligence}

The social sciences and humanities (philosophy, psychology, and sociology) have long considered the role of the emotions. From a philosophical perspective, emotions were initially considered harmful to reason. From its inception, philosophy has pursued rationalism and, therefore, believes that the reason should be used to control dangerous emotional impulses. Aristotle came up with one of the first definitions of emotions. He thought that emotions "lead to such a change in man's condition that his ability to make judgments becomes impaired, and this process is accompanied by either pleasure or pain." ${ }^{2}$ This approach to the emotions indicates that they are a basic element of "a good life," and that the nature of emotions is an integral part of all ethical analyses.

According to the Stoics, emotions manifest as conceptual errors that make us unhappy. The Stoics perceived emotions as erroneous assessments regarding life that, as such, cause suffering and frustration. Since the emotions are a source of suffering, the Stoics believed that, in order to live a good life, it is necessary to be completely detached and emotionally uninvolved.

In the Middle Ages the emotions were strictly connected with ethical considerations. For this reason, scholars and thinkers considered and analyzed primarily those emotions that were considered sinful, such as greed, jealousy, gluttony, anger, and pride.

The forefather of modern philosophy, Rene Descartes, also took up the issue of the emotions. Descartes considered the emotions to be troublesome but able to be submitted to the influence of reason. According to Descartes, emotions are kinds of passions defined as perceptions, feelings, or emotions of the soul (that are clearly connected to it) and that are triggered, sustained, and intensified by the movement of breath. ${ }^{3}$

One of the most radical Enlightenment philosophers-David Hume-believed that emotions are fundamental in ethics. Hume divided emotions into two categories: good and bad. For example,

$2 \quad$ R.C. Solomon, Filozofia Emocji, in M. Lewis, J. M. Haviland-Jones (ed.) Psychologia emocji, Gdansk 2005, pg. 21.

Ibid, pg. 23. 
according to Hume, pride is considered a good emotion, while humility, which evokes unpleasant feelings, is a bad emotion.

Immanuel Kant presented a different position on emotions. According to Kant, there is a clear division between emotions and reason. He perceived that everything great in the world was created with the participation of the passions. ${ }^{4}$ In his reflections on art and aesthetics, Kant elevated the meaning of the emotions by pointing out the delight a person experiences when considering the miraculous beauty of God's work.

In the $20^{\text {th }}$ century, Edmund Husserl, Max Scheller, Martin Heidegger, and Paul Ricoeur all emphasized the important role that emotions play in human life. Jean-Paul Sartre's conception of the emotions is, interestingly, based on the assumption that emotions are what make it possible for man to cope with difficulties realities by "magically transforming the world." 5

When considering the emotions, contemporary philosophy focuses primarily on the conceptual structure of the emotions and not on their sensory, social, or psychological aspects.

The acquisition of all skills (including emotional skills) is socially conditioned. This is the reason why sociology has examined the issue of the emotions for years in order to try to describe and explain in what way the emotions are triggered, interpreted, and expressed in the course of an individual's participation in different kinds of groups.

From a sociological perspective, the following issues pertaining to the emotions are analyzed most frequently:

- the emotional basis for social solidarity;

- determining emotions through the effects of social interaction;

- normatively regulating emotional expression and dealing with emotional deviations;

- socializing emotions by giving meaning to physiological experience;

- connecting the emotions with socially conditioned concepts of identity and one's "I;"

- differentiating emotional experiences according to social categories (e.g., social class, profession, origin, race, sex);

See I. Kant, Krytyka władzy sadzenia, trans. J. Gałecki, Warsaw 1986.

R.C. Solomon, Filozofia emocji, in M. Lewis, J. M. Haviland-Jones (eds.) Psychologia emocji, Gdansk 2005, pg. 26. 
- emotions involved in large-scale social processes (e.g., stability or change) ${ }^{6}$

Sociology is interested in emotions primarily as a non-verbal form of communication. ${ }^{7}$

Psychological literature has yet to provide a uniform definition of emotions. Some psychologists define emotions as particular states, while others treat them as a process. Emotional processes are referred to as subjective feelings and occurrences that can be measured both physiologically and behaviorally. Frequently literature on psychology states that emotions are experienced in relation to themselves or in relation to one's surroundings. The sources of emotions, therefore, can be seen in objective reality, since man, reflecting his feelings, responds to this reality by either enjoying, sorrowing, loving, or suffering. ${ }^{8}$

The term "emotional intelligence" is controversial, and theoretical data on the topic is still full of insinuations and even often contradictions. Consequently, it is difficult to say whether EI should be treated as an ability, a competence, a skill, or a set of convictions. Since a definitive position has not been determined in this area, different theoretical studies present varying perspectives. For this reason, it is currently difficult to present a definitive and coherent definition of the term "EI."

J. Mayer and P. Salovey's capacity model $^{9}$ as well as D. Goleman ${ }^{10}$ and R. Bar-On's ${ }^{11}$ so-called "mixed models" by are the most frequent models and concepts of EI that appear in scientific research. Initially, Salovey and Mayer distinguished three (and then four) groups of components of EI when observing the development aspect in light of a group of different abilities that comprise EI. They arranged these individual components into a hierarchy, at the bottom of which are the basic skills of perception and emotional expression, and at the top of which is the reflective and conscious regulation of emotions that

$6 \quad$ T.D. Kemper, Modele społeczne w wyjaśnianiu emocji, in M. Lewis, J. M. Haviland-Jones (eds.), Psychologia emocji, Gdansk 2005, pg.73.

A. Giddens, Socjologia, Warsaw 2005, pg. 105.

M. Przetacznik-Gierowska, G. Makiełło-Jarża, Podstawy psychologii ogólnej, Warsaw 2001, pg. 79.

P. Salovey, J.D. Mayer, Emotional intelligence, "Imagination, Cognition, and Personality," 1990, 9.

10 D. Goleman, Inteligencja emocjonalna, Poznan, 1997; D. Goleman, Inteligencja emocjonalna $w$ praktyce, Poznan 1999.

11 R. Bar-On, EQ-i. BarOn Emotional Quotient Inventory. A Measure of Emotional Intelligence. User's Manual, Toronto 1997. 
favor personal understanding and development. ${ }^{12}$ According to Salovey and Mayer, the acquisition of emotional skills lasts a lifetime, whereas attaining the individual skills in the EI model requires continual commitment and effort. It seems, however, that people with high EI pass through the stages of acquiring new skills more quickly, and they are able to master more of these skills.

Despite the many doubts (evidenced by empirical data) about the uniformity of EI, ${ }^{13}$ it is likely the only existing consistent model of what can be called "intelligence." This is justified by the following criteria: the potential to operationalization individual components understood as capabilities; the criteria that are met are correlated with the standard intelligence measured; and an increase in the level of EI depending on age. ${ }^{14}$

While many researchers consider the EI model presented above dubious, ${ }^{15}$ it is likely the only model that can currently be labeled "intelligence." The following criteria support this claim:

- the ability to operationalize specific components understood as abilities;

- fulfilled criteria that correlate with the standard of the measured intelligence;

- an increase in EI level depending on age. ${ }^{16}$

The second theoretical trend in EI is a mixed model created by D. Goleman. In his bestselling book, Goleman asserts that EI includes the following abilities: to be motivated, to persevere in the pursuit of one's goals despite failures, to control one's drives and postpone

12 P. Salovey, J.D. Mayer, Emotional Intelligence, "Imagination, Cognition, and Personality," 1990. 9, pgs. 185-211.

13 See A.L. Day, S.A. Carroll, Using an Ability-Based Measure of Emotional Intelligence to Predict Individual Performance, Group Performance and Group Citizenship Behaviors, "Personality and Individual Differences," 36, 2004; J.D. Mayer et al., Measuring Emotional Intelligence with the MSCEIT V2.0, "Emotion 3," 2003; J.V. Ciarrochi, A.Y.C. Chan, and P. Caputi, A Critical Evaluation of the Emotional Intelligence Construct, "Personality and Individual Differences," 28, 2000 .

14 J.D. Mayer, A Field Guide to Emotional Intelligence, "Emotional intelligence and everyday life,” J. Ciarrochi, J. P. Forgas, J. D. Mayer (eds.), New York: Psychology Press, 2001.

15 See A.L. Day, S.A. Carroll, Using an Ability-Based Measure of Emotional Intelligence to Predict Individual Performance, Group Performance and Group Citizenship Behaviors, "Personality and Individual Differences" 36, 2004.

16 J. D. Mayer, A Field Guide to Emotional Intelligence, "Emotional Intelligence and Everyday life," J. Ciarrochi, J. P. Forgas, J. D. Mayer (eds.), New York: Psychology Press, 2001. 
their satisfaction, to regulate one's mood and not give into worry that disables one's ability to think, to empathize with others, and to have an optimistic outlook on the future. ${ }^{17}$ This model is considered mixed because it combines various aspects: cognitive, individualistic, motivational, and emotional. Critics do not consider this concept as scientific theory; instead, they regard it as a collection of information about the ability to function well in life by developing one's own emotional potential.

Rueven Bar-On's model of EI is also a mixed model. This theorist defines EI as a series of non-cognitive abilities, competences, and skills that enable an individual to deal effectively with environmental demands and pressures. ${ }^{18}$ The basic components of this model are: self-awareness, understanding one's strengths, perceiving one's weaknesses, and the ability to constructively express one's feelings and thoughts. The interpersonal plane includes an ability to know the emotions, feelings, and needs of others, as well as an ability to establish and maintain satisfactory interpersonal relationships. According to Bar-On, EI also entails an ability to effectively cope with changes that take place in one's personal and professional life by being flexible and creative in different life situations.

Up to now, studies on these phenomena have focused on determining the relationship between, for example, EI and academic success in college and during the first year of university studies. ${ }^{19}$ Studies on professional groups (managers, psychotherapists) confirm that people who are emotionally intelligent are more successful in their professional life.$^{20} \mathrm{EI}$ is particularly significant in professions that involve interpersonal and communication-based cooperation. For this reason, EI is undoubtedly an important component of teaching competences. EI directs emotional energy by strengthening communication and interpersonal competences and motivating individuals to make socially valuable decisions. ${ }^{21}$ An emotionally intelligent teacher is able

D. Goleman, Inteligencja Emocjonalna, Poznan, 1997, pg. 67.

R. Bar-On, EQ-i. BarOn Emotional Quotient Inventory, pg. 3.

See Schutte, Malouff, Hall, Haggerty, Cooper, Golden, Dornheim, per A. Jaworowska, A. Matczak, Kwestionariusz Inteligencji Emocjonalnej INTE, Warsaw 2001.

Por. R.K. Cooper, A. Sawaf, EQ. Inteligencja emocjonalna w organizacji i zarzadzaniu. Warsaw, 2000; D. Goleman, Inteligencja emocjonalna w praktyce, Poznan 1999.

Por. P. Salovey, D.J. Sluyter, Rozwój emocjonalny a inteligencja emocjonalna. Poznan 1999, pgs. 335-339. 
to ascertain more thoroughly in what kinds of relationships his or her emotionality affects the attitudes and behaviors of his or her students. An emotionally competent teacher is also able to: appreciate and reward students' abilities and achievements; help students in their intellectual development; be involved in students' intellectual inquiries; and serve as a personal example to students. Such a teacher is able to understand different points of view and perceive the driving force of development in this variety.

\section{Methodological Assumptions}

The main question that this research seeks to address is: What is the EI level of teaching candidates?

This study assumes that the state and level of the teaching candidates' EI will be either average or low. The indicators of the candidates' EI level was determined by taking the sum of the points obtained when completing the INTE Emotional Intelligence Questionnaire (165 points total).

The items listed on the questionnaire follow Salovey and Mayer's EI model's assumptions. Therefore, 13 questions pertain to the perception, assessment, and expression of emotions; 10 questions pertain to the regulation of emotions; and 10 questions pertain to the use of emotions to think and act.

Table 1. Research Sample According to the Following Independent Variables

\begin{tabular}{|c|c|c|c|c|c|c|c|c|c|c|}
\hline & \multicolumn{2}{|l|}{ Sex } & \multicolumn{3}{|c|}{ Education Level } & \multicolumn{4}{|c|}{ Academic Profile } & \multirow[b]{2}{*}{ Total } \\
\hline & हี & $\sum^{\tilde{e}}$ & 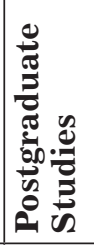 & 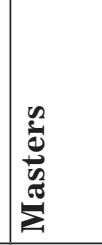 & 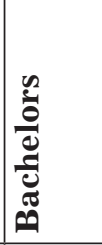 & 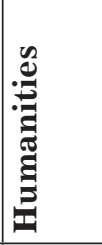 & 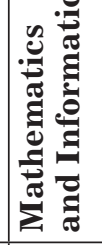 & 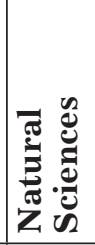 & 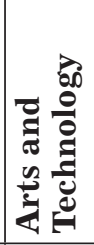 & \\
\hline$\#$ & 40 & 9 & 1 & 3 & 45 & 12 & 12 & 25 & 0 & 49 \\
\hline$\%$ & 81.6 & 18.4 & 2 & 6.1 & 91.8 & 24.5 & 24.5 & 51 & 0 & 100 \\
\hline
\end{tabular}

Source: author's calculations

Fifty students from the Pedagogy Track of study participated in this study, which was conduced in 2017 as part of the Center for Long-Term Education at the University of Bialystok. Among the 50 participants, only 49 filled out the questionnaire correctly. The respondents were 
made up of 40 women and 9 men. One participant had been enrolled in postgraduate studies; 3 people had a master's degree; and 45 individuals $(91.8 \%)$ had a bachelor's degree.

Among the respondents, $24.5 \%$ were specializing in the humanities, $24.5 \%$ were specializing in mathematics and informatics, and $25 \%$ were specializing in mathematics and the natural sciences.

The respondents' level of EI was determined based on the INTE Emotional Intelligence Questionnaire prepared by N. S. Schutte, J. M. Malouff, L. E. Hall, D. J. Haggerty, J. T. Cooper, C. J. Gloden, and L. Dornheim, and adapted to Polish by Aleksandra Jaworowska and Anna Matczak. ${ }^{22}$ The INTE is made up of 33 self-reported items whose truthfulness in relation to one's own person is assessed on a five-point Likert scale. Analysis of the results was carried out using the SPSS 23.0, and the hypothesis was verified at a significance level of 0.05 .

\section{Study Results}

EI cannot be underestimated today. Although the family is the primary place in which individual's emotions become socialized, ${ }^{23}$ people are expecting that emotional education should also play an increasing role in schools and taught by competent teachers. ${ }^{24}$ In this context, it is important to examine whether teaching candidates demonstrate high EI, which is a very important quality to have when establishing and fostering good relationships with students and developing their EI.

Table 2. EI Level According to According to Sex

\begin{tabular}{|c|c|c|c|c|c|c|c|c|}
\hline \multirow{3}{*}{$\begin{array}{c}\text { Emotional } \\
\text { Intelligence } \\
\text { Level }\end{array}$} & \multirow{2}{*}{\multicolumn{2}{|c|}{ Women }} & \multirow{2}{*}{\multicolumn{2}{|c|}{ Men }} & \multirow{2}{*}{\multicolumn{2}{|c|}{ Total }} & \multirow{2}{*}{\multicolumn{2}{|c|}{$\begin{array}{c}\text { Difference by } \\
\text { Sex }\end{array}$}} \\
\hline & & & & & & & & \\
\hline & $N=40$ & $\%$ & $N=9$ & $\%$ & $N=49$ & $\%$ & Sig. & p.i. \\
\hline High Level & 6 & 15 & 1 & 11.1 & 7 & 14.3 & \multirow{3}{*}{.595} & \multirow{3}{*}{ n.i. } \\
\hline Average Level & 28 & 70 & 6 & 66.7 & 34 & 69.4 & & \\
\hline Low Level & 6 & 15 & 2 & 22.2 & 8 & 16.3 & & \\
\hline
\end{tabular}

Source: author's calculations

22 A. Jaworowska, A. Matczak, Kwestionariusz Inteligencji Emocjonalnej INTE, Warsaw 2001.

$23 \quad$ K. Oatley, J. Jenkins, Understanding Emotions, Wiley Blackwell, 1996.

24 See P. Salovey, D.J. Sluyter, Rozwój emocjonalny a inteligencja emocjonalna, Poznan 1999, pg. 253. 
An analysis of the study results indicates that women show a $3.9 \%$ higher level of EI than men. This follows the theory of the lateralization of the emotional processes that take place in the brain. According to this theory, men exhibit lower emotional proficiency than women due to the fact that their brains are more lateralized and the left hemisphere of their brains (which is responsible for verbalization of emotions) is dominant. Recognition of emotions, however, is a process that takes place in the right hemisphere of the brain. Women's brains, on the other hand, are less lateralized than men, and neither side of their brain (left or right) is primarily dominant. As a result, they often have a greater ability to orientate themselves in their own subjective and somatic states. ${ }^{25}$ In order to better understand these differences, it is worthwhile to refer to Tomasz Maruszewski and Elzbieta Scigala's concept of the psychic representation of emotions. According Maruszewski and Scigala, emotions are represented on three interrelated levels: pictorial (including, among other things, somatic experiences related to emotions); verbal (the expression of emotions through words); and abstract (the analysis of the meaning of emotions).

Because women do not have strong functional emotional predominance of the left hemisphere of the brain, it can be difficult for them to find the verbal expressions necessary to describe the emotional states that they are experiencing. They understand emotions, even though they are unable to describe them precisely using words. ${ }^{26}$

Men, however, demonstrate a lower level of EI than women, which the aforementioned theory confirms.

Table 3. Emotional Intelligence Level According to Education Level

\begin{tabular}{|c|c|c|c|c|c|c|c|c|c|c|}
\hline \multirow{2}{*}{$\begin{array}{c}\text { Emotional } \\
\text { Intelli- } \\
\text { gence Level }\end{array}$} & \multicolumn{2}{|c|}{$\begin{array}{l}\text { Postgradu- } \\
\text { ate Level }\end{array}$} & \multicolumn{2}{|c|}{$\begin{array}{c}\text { Master's } \\
\text { Level }\end{array}$} & \multicolumn{2}{|c|}{$\begin{array}{c}\text { Bachelor's } \\
\text { Level }\end{array}$} & \multicolumn{2}{|c|}{ Total } & \multicolumn{2}{|c|}{$\begin{array}{c}\text { Differ- } \\
\text { ence by } \\
\text { Education }\end{array}$} \\
\hline & $\mathbf{N}=1$ & $\%$ & $\mathbf{N}=3$ & $\%$ & $N=45$ & $\%$ & $N=49$ & $\%$ & Sig. & p.i. \\
\hline High Level & 0 & 0 & 1 & 33.3 & 6 & 13.3 & 7 & 14.3 & \multirow{3}{*}{.211} & \multirow{3}{*}{ n.i. } \\
\hline $\begin{array}{l}\text { Average } \\
\text { Level }\end{array}$ & 0 & 0 & 1 & 33.3 & 33 & 73.3 & 34 & 69.4 & & \\
\hline Low Level & 1 & 100 & 1 & 33.3 & 6 & 13.3 & 8 & 16.3 & & \\
\hline
\end{tabular}

Source: author's calculations

The research results show that teaching candidates who are studying at the bachelor's level (13.3\%) and the master's level (33.3\%) show the highest levels of EI. Surprisingly, the respondents who were

\footnotetext{
25 T. Maruszewski, E. Ścigała, Emocje - aleksytymia - poznanie, Poznan 1998.

$26 \quad$ Ibid, pg. 198.
} 
postgraduates demonstrated the lowest level of EI, which may suggest that a higher level of education is not necessarily an indicator of high emotional proficiency.

A comparison of the study results based on education level is promising. While the bachelor's students achieved a high level of EI at only $13.3 \%$, the master's level students EI increased by as much as $20 \%$, thereby indicating that EI levels increase as students pass through subsequent stages of their academic education.

Anthropology Table 4. Emotional Intelligence Level According to Academic Profile

\begin{tabular}{|c|c|c|c|c|c|c|c|c|c|c|}
\hline \multirow[t]{2}{*}{$\begin{array}{l}\text { Emotional } \\
\text { Intelligence } \\
\text { Level }\end{array}$} & \multicolumn{2}{|c|}{$\begin{array}{l}\text { Humani- } \\
\text { ties }\end{array}$} & \multicolumn{2}{|c|}{$\begin{array}{l}\text { Math- } \\
\text { ematics \& } \\
\text { Informatics }\end{array}$} & \multicolumn{2}{|c|}{$\begin{array}{l}\text { Biology \& } \\
\text { Chemistry }\end{array}$} & \multicolumn{2}{|l|}{ Total } & \multicolumn{2}{|c|}{$\begin{array}{l}\text { Differ- } \\
\text { ence by } \\
\text { Academ- } \\
\text { ic Profile }\end{array}$} \\
\hline & $\mathrm{N}=12$ & $\%$ & $\mathrm{~N}=12$ & $\%$ & $N=25$ & $\%$ & $N=49$ & $\%$ & $\mathbf{F}$ & p.i. \\
\hline High Level & 1 & 8.3 & 1 & 8.3 & 5 & 20.0 & 7 & 14.3 & \multirow{3}{*}{.578} & \multirow{3}{*}{ n.i. } \\
\hline Average Level & 8 & 66.7 & 10 & 83.3 & 16 & 64.0 & 34 & 69.4 & & \\
\hline Low Level & 3 & 25.0 & 1 & 8.3 & 4 & 16.0 & 8 & 16.3 & & \\
\hline
\end{tabular}

Source: author's calculations

Data analysis shows that the level of EI of future teachers differs based on academic profile (see Table 4). Those who study biology and chemistry have a higher level of EI than those who study other subjects $(20.0 \%$ of respondents in this group demonstrated a high level of emotional ability, while only around $8.3 \%$ of the candidates for teachers who were educated in the humanities and mathematics-informatics showed a high level). One might wonder why the humanities students were found to have lower results, especially since, according to popular opinion, individuals who study the humanities are sensitive, empathetic, and easily identify and express their emotional states. However, according to the results, up to $25 \%$ of the humanities students surveyed demonstrated a low level of EI.

\section{Conclusions and Practical Implications}

The students enrolled in the Pedagogical Course are from different academic backgrounds. These future teachers, educators, and pedagogues will likely play a significant role in the lives of many of their students both inside and outside of the classroom. When teachers intentionally strengthen their ability to deal with their own and other people's emotions in the context of everyday experiences, they help others become actively involved and create the foundation for their 
students to experience years of success in both school and life. This, however, is possible only if teachers themselves have a high level of EI.

In light of theoretical principles, the practical implications of the results of this study are interesting and demonstrate that:

- women have a $15 \%$ higher level of emotional intelligence,

- $33 \%$ of the respondents with a master's degree reported a high level of EI; $13.3 \%$ of students at the bachelor degree demonstrated a high level of EI; while $0 \%$ of the postgraduate students demonstrated a high level of EI.

- $20 \%$ of the respondents with a biology-chemistry academic profile showed high EI.

In this study, the respondents are students enrolled in the Pedagogical Course and preparing to become future teachers. In addition to their didactic preparation, which will enable them to teach certain subjects (among other things), the students are also enrolled in an extensive series of classes in pedagogy and psychology. In the other courses that they are taking in their fields of specialization, these students will likely encounter content that will help them to develop their emotional competence.

The purpose of educating teaching candidates to become emotionally competent is to enable them to have a well-conceived idea of emotional education, since students acquire some of the most important knowledge in EI when interacting directly with their teachers. ${ }^{27}$ Moreover, only an emotionally competent teacher is able to introduce a student or young person into the difficult and unpredictable world that Umberto Eco calls "dangerous," which is fitting because this postmodern world is one of permanent transition and one in which conflicting realities-both old and new-clash. ${ }^{28}$

\section{INTELIGENCJA EMOCJONALNA KANDYDATÓW NA NAUCZYCIELI}

Ludzkie umiejętności „radzenia sobie w życiu” nie opierają się tylko na umiejętnościach kognitywnych, co ogłosił pod koniec XX wieku Daniel Goleman, a co spowodowało zdecydowany zwrot w myśleniu o „wyposażeniu emocjonalnym" człowieka. Umiejętności emocjonalne są w dużej mierze wrodzone, jednak z pewnością, co potwierdzają współczesne badania, można je rozwijać. I rzeczywiście ostatnio coraz większe zainteresowanie badań w naukach

27 See P. Salovey, D.J. Sluyter, Rozwój emocjonalny a inteligencja emocjonalna, Poznan 1999, pg. 51.

28 U. Eco, Semiologia życia codziennego, Warsaw 1996, pg. 91. 
społecznych koncentruje się wokół obszaru inteligencji emocjonalnej, która stanowić może ważne determinanty jakości edukacji.

W artykule zostały przedstawione wyniki badań, mających na celu rozpoznanie stanu inteligencji emocjonalnej studentów przygotowujących się do pełnienia roli nauczyciela. Jest to fragment szerszego projektu badawczego, w którym poszukiwane są czynniki emocjonalne wspierające proces edukacji.

Słowa kluczowe: inteligencja emocjonalna, kandydaci na nauczycieli.

\section{Bibliography:}

1. Bar-On R., EQ-i. BarOn Emotional Quotient Inventory: A Measure of Emotional Intelligence, User's Manual, Toronto 1997.

2. Ciarrochi J.V., Chan A.Y.C., Caputi P., A Critical Evaluation of the Emotional Intelligence Construct, "Personality and Individual Differences" 28, 2000.

3. Cooper R.K., Sawaf A., EQ. Inteligencja emocjonalna w organizacji i zarzadzaniu, Warsaw 2000.

4. Day A.L., Carroll S.A., Using an Ability-Based Measure of Emotional Intelligence to Predict Individual Performance, Group Performance and Group Citizenship Behaviors, "Personality and Individual Differences" 36, 2004.

5. Eco U., Semiologia życia codziennego, Warsaw 1996.

6. Giddens A., Socjologia, Warsaw 2005.

7. Goleman D., Inteligencja emocjonalna w praktyce, Poznan 1999.

8. Goleman D., Inteligencja emocjonalna, Poznan 1997.

9. Jaworowska A., Matczak A., Kwestionariusz Inteligencji Emocjonalnej INTE, Warsaw 2001.

10. Kant I., Krytyka wtadzy sądzenia, (trans.) J. Gałecki, Warsaw 1986.

11. Kemper T.D., Modele społeczne w wyjaśnianiu emocji, in M. Lewis, J. M. Haviland-Jones (eds.) Psychologia emocji, Gdansk 2005.

12. Mayer J.D., A Field guide to Emotional Intelligence, "Emotional Intelligence and Everyday Life,” J. Ciarrochi, J. P. Forgas, J. D. Mayer (Eds.), New York: Psychology Press, 2001.

13. Mayer J.D. et al., Measuring Emotional Intelligence with the MSCEIT V2.0, "Emotion 3," 2003.

14. Oatley K., Jenkins J., Understanding Emotions, Wiley Blackwell, 1996.

15. Przetacznik-Gierowska M., Makiełło-Jarża M., Podstawy psychologii ogólnej, Warsaw 2001.

16. Salovey P., Mayer J.D., Emotional Intelligence, "Imagination, Cognition, and Personality," 1990. 9.

17. Salovey P., Sluyter D.J., Rozwój emocjonalny a inteligencja emocjonalna, Poznan 1999.

18. Schunk D., Commentary on Self-Regulation in School Contexts, "Learning and Instruction" 2005, 15.

19. Solomon R.C., Filozofia emocji, in M. Lewis, J. M. Haviland-Jones (eds.) Psychologia emocji, Gdansk 2005. 